\title{
The Most Influential Aspects of the Phenomenon Public Space in Jalan Wisata Kerto Menanggal
}

\author{
Shabrina Nareswara, Purwanita Setijanti, and Murni Rachmawati \\ Department of Architecture, Institut Teknologi Sepuluh Nopember, Surabaya \\ e-mail:p.setijanti@arch.its.ac.id
}

\begin{abstract}
Abstrak-Public space is one of the important components in the city and participates in improving the quality of life of the people in a city. The city of Surabaya as the capital of East Java with high public space development needs, often the development of public space is more concentrated in the city center. The Public Space of Menanggal Tourism Road located on the border of Surabaya City and Sidoarjo Regency is experiencing a phenomenon that causes a decrease in the image of the region and abuse of the function of public facilities. Behavior of users of public space at the time of the phenomenon is the key to the occurrence of the problem. Therefore an appropriate theoretical approach is needed to understand the phenomenon as a whole. Behavior setting is an approach that connects activity patterns and behavior patterns in a physical environment that is used to understand the phenomenon. This research uses naturalistic paradigms and qualitative strategies with data collection techniques using observation and in-depth interviews. To identify the aspects that most influence on the formation and continuity of the phenomenon of the Tourism Road Region to date these data, data analysis using the Miles and Huberman model is used. The results showed that the affective meaning and activity system were the most influential aspects in the continuity of the phenomenon. These aspects can be used as a basis for developing concepts to overcome the problems that arise during the phenomenon.
\end{abstract}

Kata Kunci-Behavior Settings, Places, Public Spaces.

\section{INTRODUCTION}

$\mathrm{S}$ PACE is an important element that influences the formation of the quality of a city. Space starts from a point, then the point forms a line, and the line forms a plane, until finally the plane becomes space. The modern city conception asserts that urban space consists of the organization of private and public spaces in which the people have an equal conception of urbanity, having the same goal of shared life [6]. Awareness that cities are not only formed through public private space, but through public space which gives meaning that the sustainability of a city is also very dependent on the accuracy of planning public spaces in it.

The relationship between public space and private space forms a social space for permanent residents, temporary residents, and migrants or tourists. There are three kinds of social spaces that are formed, namely: open spaces (accepting anyone), open spaces but have special limitations, and spaces that are strictly separated private spaces [4]. Social space is a link between public and private space. Comprehensive development of a space is not only limited to the interests of private and public needs that are built, but also open spaces

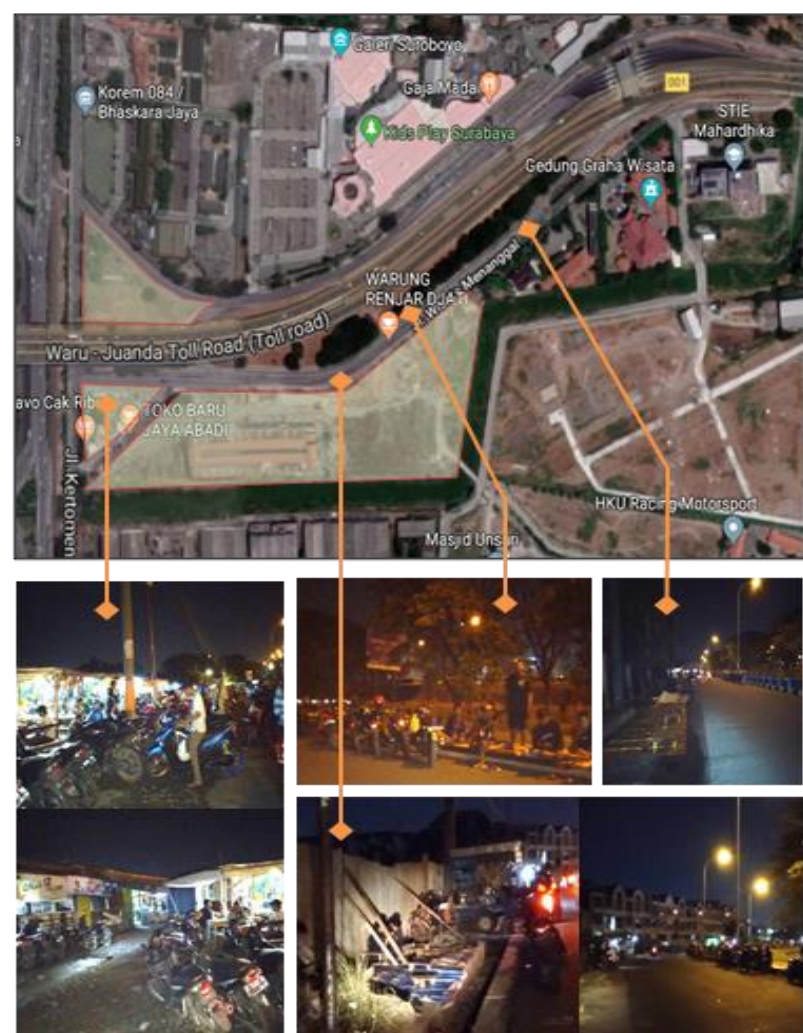

Figure 1. Existing

either residual, connecting or have special functions. Open spaces are included in the category of public space. Open space is land and water in urban areas that are not covered by cars or buildings, or land that has not yet been developed in urban areas [3]. This explanation interprets that an open space is a plot of land or water whether planned or unplanned.

These spaces have each role within the city. The need for public space in urban areas continues to increase with the rapid growth of a city. Increasingly densely populated cities are directly proportional to the increasing need for public space, including public open space.

In addition to fulfilling the quantity, equitable development of public space (especially public open space) is also crucial given the increasing population density. Changes in land use that are already limited require wise and appropriate actions so that the composition of public space is maintained. Intersection of accuracy and suitability of changes in land use as a public space and an increase in the need for public open space becomes important. The suitability of the type of public 
The $6^{\text {th }}$ International Seminar on Science and Technology (ISST) 2020

July $25^{\text {th }} 2020$, Institut Teknologi Sepuluh Nopember, Surabaya, Indonesia

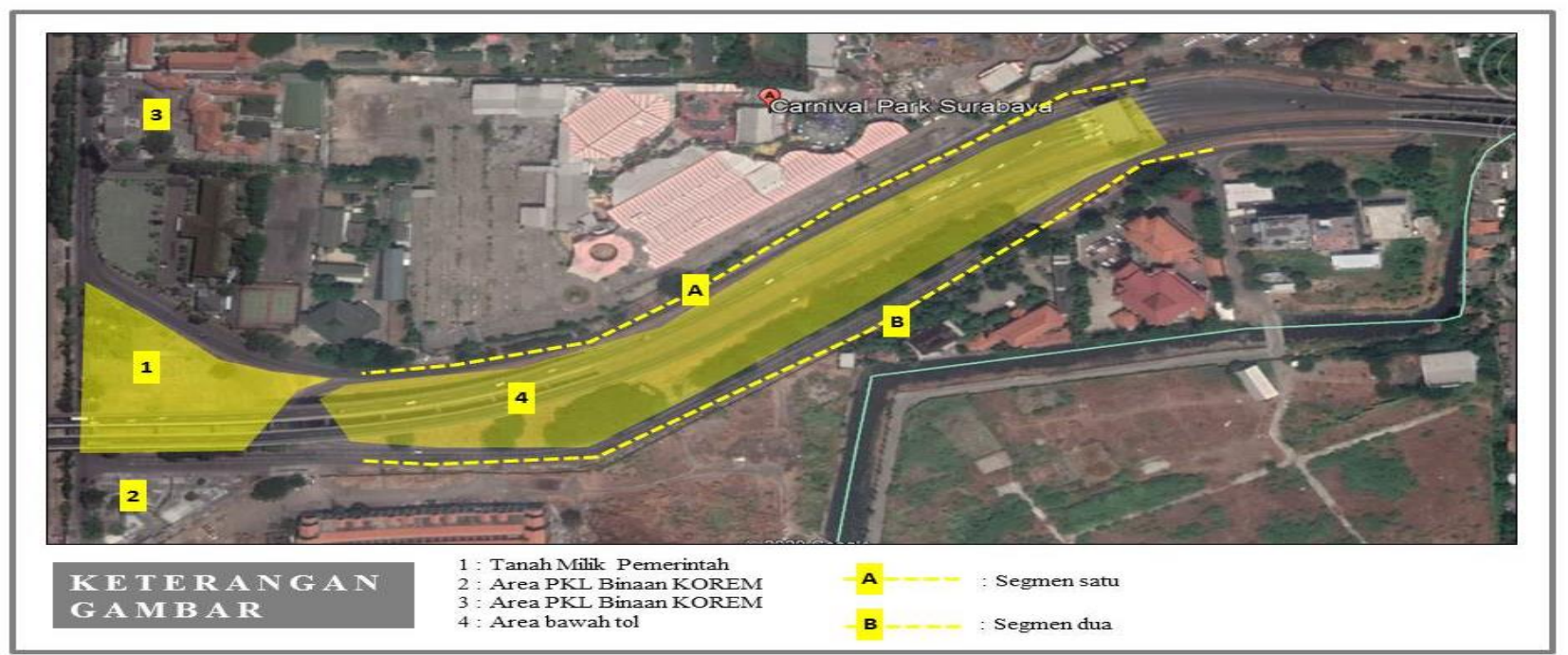

Figure 2. Segmentation.

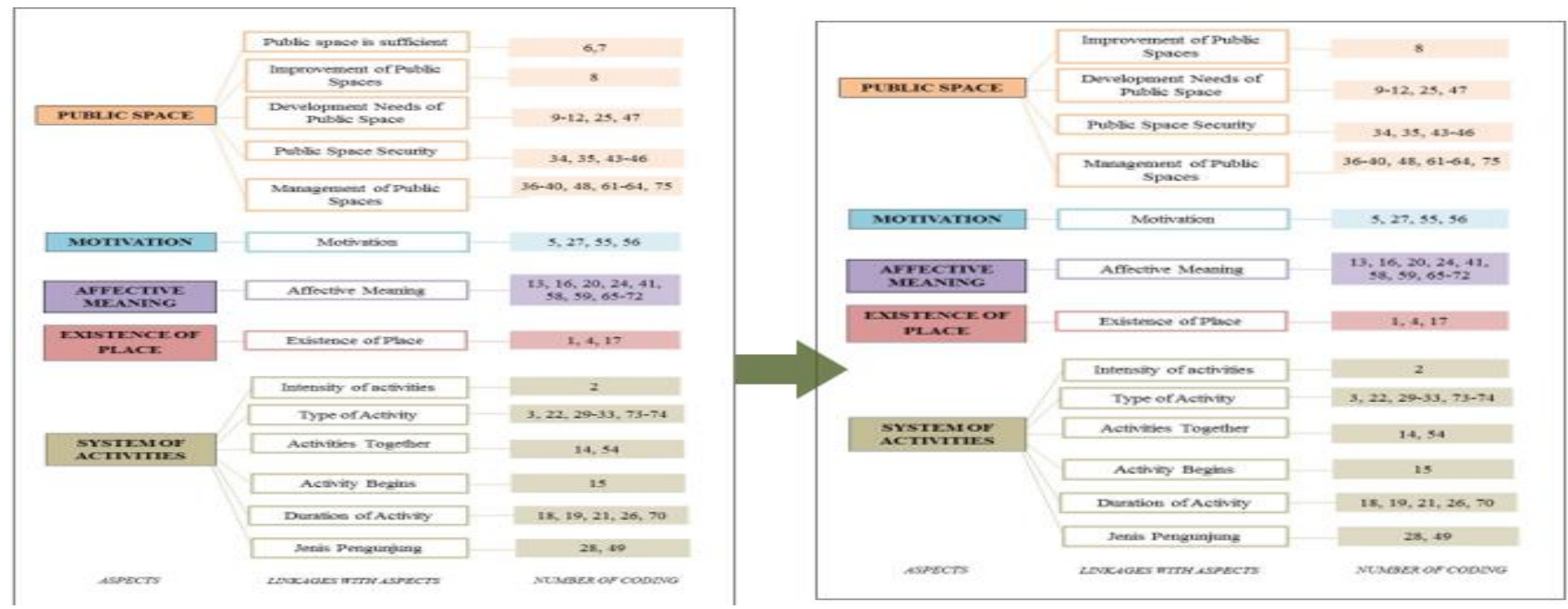

Figure 3. collection data to reduction data.

space that is present with the needs of the local community is an important factor for the success of a public space. Therefore, the success of public space is not only seen from physical awakening, but also its ability to respond to human needs as users. In the Menanggal Tourism Region there is a phenomenon of spontaneous pubic open space due to the inability of public spaces to accommodate social interactions that form regularly at night, when people want to let go of fatigue or recreation. This phenomenon is characterized by the existence of informal economic activities carried out by street vendors and the dysfunction in the use of public facilities by residents. This study aims to find what aspects are most influential in the continuity of the phenomenon with the behavior setting approach. Exizting can see Figure 1.

\section{THEORY}

Public open space plays an important role in determining the quality of a city. This explains that in the future the quality of a city will be determined by the quality of the open spaces inside. Public open space as an element that is not built (void) is part of public space. In the distribution of types of public space according to Carmona (2003), public open space into the type of "External Public Space" [1]. Where the notion of "External Public Space" is public space in the form of outdoor space that can be accessed by everyone (public).

According to Carmona (2008), Public space has several types based on its function including positive space, negative space, ambiguous space [1]. Of the several types, it can be analyzed that open space in the Menanggal Tourism Area is included in the negative space category. With this research, it is expected that the function of public open space in the region will change to positive space. The existence of public open space in a city has benefits and potential which are summarized into four main areas namely social, health, environment and economy.

From the context of the phenomenon in the Menanggal Tourism Area through the Behavior Setting Theory perspective, the researcher wants to dig deeper into the visitors' perceptions of the room experience on the two roads. The meaning engraved in the mind shapes and moves attitudes which are then translated into activities. Activities that are repeated over a period of time form a pattern. Through the analysis of the understanding of visitor perceptions, it is expected to be able to describe the concept 
The $6^{\text {th }}$ International Seminar on Science and Technology (ISST) 2020

July $25^{\text {th }} 2020$, Institut Teknologi Sepuluh Nopember, Surabaya, Indonesia

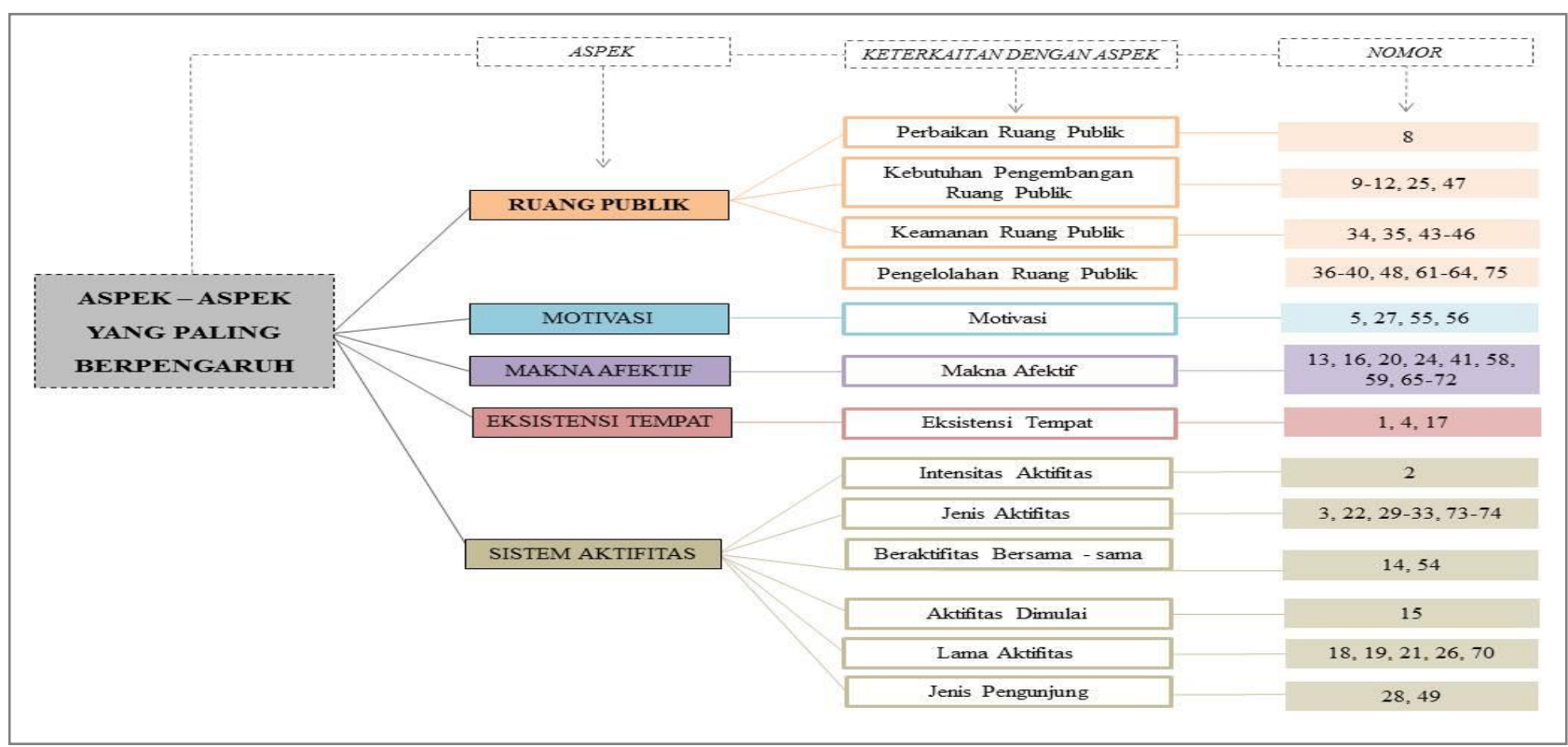

Figure 4. Diagram Conclusion.

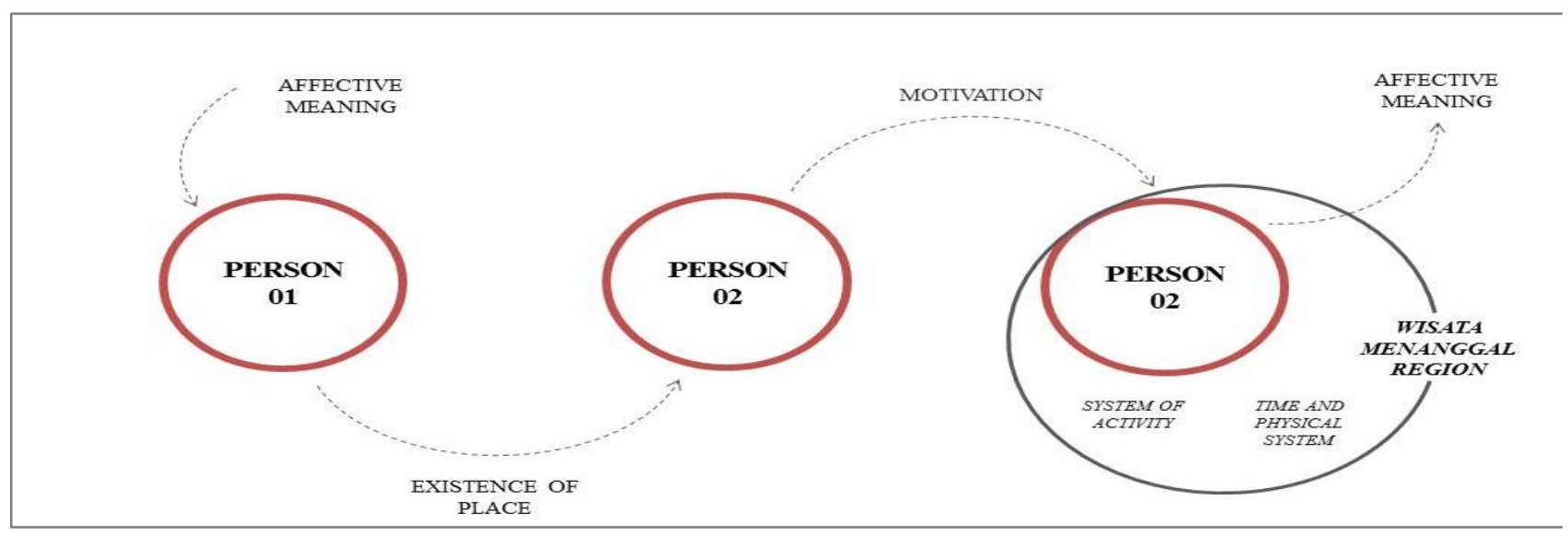

Figure 5. People's Cycle to the place.

of public open space in accordance with the existing context and problems.

The above review explains that in identifying an area one can use several behavioral setting criteria which are divided into four sections, namely [5]:

\section{1) There are patterned activities (standing pattern of behavior)}

In the study area, activities that arise in the period of occurrence of phenomena can be said to be patterned if they experience repetition by strengthening the existence of the phenomenon. As explained in the background, the main activities are traders and visitors who interact socially. Traders can indicate the type of activity that occurs between visitors. However, a deeper observation of visitor behavior can show the potential for other activities not related to traders.

\section{2) Being in a certain environmental system (circumjacent milieu)}

Certain environment is the boundaries of the environment in the area that stimulates the occurrence of activity on the phenomenon. As in the area there are many components, not all parts of the region are certain environments (circumjacent milieu) forming the phenomenon. However, some parts of the region, in this study open space, become a stimulus for the formation of certain environmental phenomena.

\section{3) Formed a relationship between milieu and behavior (synomorphy)}

Relationships between behaviors that produce activities have dependencies or relationships that are equivalent to the determination of a particular milieu or environment.

\section{4) Done at certain periods of time}

The period of time the phenomenon occurs in the region is defined from the time of repetition of the activity pattern. The time period contains a long time.

\section{METHODOLOGY}

The research paradigm is used by researchers as a guide in understanding the context of the research being undertaken, in which it contains the assumptions and all the realities inherent in the area of research. In this study the research subject position is the user of the Menanggal Tourism Area. 
The $6^{\text {th }}$ International Seminar on Science and Technology (ISST) 2020

July $25^{\text {th }}$ 2020, Institut Teknologi Sepuluh Nopember, Surabaya, Indonesia

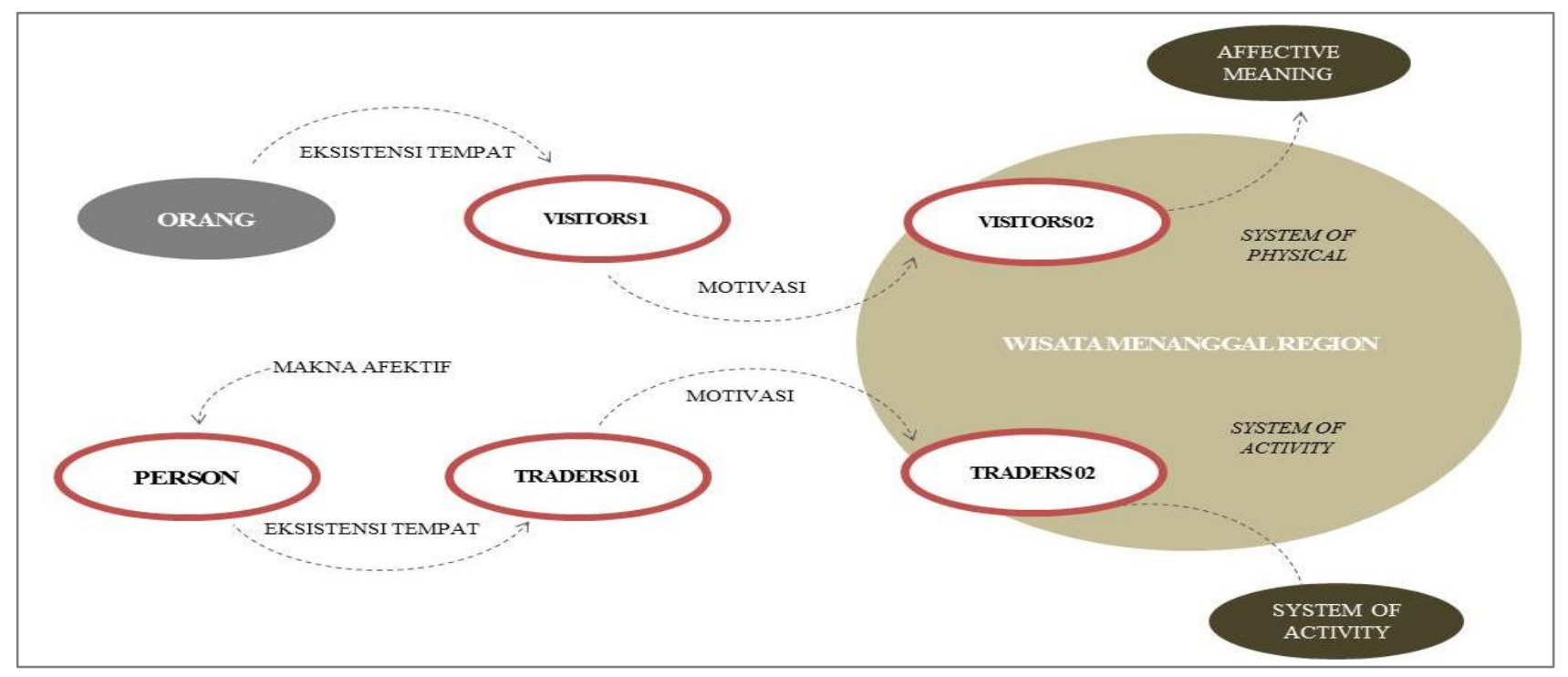

Figure 6. How to people reach the place.

Table 1.

Conclusion

\begin{tabular}{lll}
\hline \multicolumn{1}{c}{ Aspects } & Sub-Aspect & \multicolumn{1}{c}{ Description } \\
& - & Mood when in the area \\
\hline Affective Meaning & type & Dominated by eating and drinking \\
& Intensity & The intensity of attendance is rare but once comes a long duration \\
Activity & Duration & The duration of time when in the area \\
& - & Verbal knowlegde \\
Exixtence of Place & - & Basic desire (reason) someone visiting the area. \\
Motivation &
\end{tabular}

While the object of research is aspects that form phenomenology in the Menanggal Tourism Area. With this in mind, this study uses a naturalistic paradigm. In Groat and Wang (2013) it is stated that the naturalistic paradigm is also called the qualitative or interpretative constructivism paradigm [2].

The naturalistic paradigm understands reality as something that is socially constructed. Naturalistic adopts subjective epistemology where knowledge arises from the researcher and or respondent together making an understanding of the situation or context being studied. In environmental research and design, the naturalistic paradigm seeks to explain in depth insights and interpretations of the settings provided from the perspective of individuals who experience the environment [2]. This Menanggal Tourism Area study uses a naturalistic paradigm as a response to phenomena that occur at certain periods in the region. Public space users are the key and the subject of this research. The deepening of users' perceptions and interpretations of the environment occurrence of phenomena becomes the background of naturalistic paradigm selection. The initial stage will be taken field facts regarding the perceptions of users according to user-defined classifications. Furthermore, the facts were analyzed by the miles and Huberman model, then validated again using triangulation analysis based on data sources. the use of layered analysis will strengthen the accuracy of research results.

\section{RESULT AND DISCUSSION}

In-depth interviews were conducted based on the division of regional segments. Kerto Menanggal Tourism Road consists of two road sections north and south, so the segmentation is in accordance with the following figure 2.

Analysis of the deepening of the meaning created in the minds of users of public spaces in the Menanggal Tourism Area using in-depth interviews. Users of Menanggal Tourism Area Public Spaces are classified into two types, namely traders and visitors. Furthermore, in accordance with the division of environmental boundaries (circumjacent milieu), interviews were conducted in each segment with representatives of each classification of user types, namely visitors and traders. After conducting interviews, transcripts are transformed into narrative forms and then processed into qualitative data analysis models of Miles and Huberman. The results of the interview are separated by each sentence and the overall data yields 75 sentences. Furthermore, compaction of the facts of each sentence and interpreted into several categories. The analysis produces several categories that refer to several aspects, namely:

\section{1) Public Spaces and Existence of Places}

In the category of public space obtained psychological facts interpretation of management, security, improvement of 
The $6^{\text {th }}$ International Seminar on Science and Technology (ISST) 2020

July $25^{\text {th }} 2020$, Institut Teknologi Sepuluh Nopember, Surabaya, Indonesia

public space. Very crucial thing is a repair problem.

Whereas in the category of place existence, psychological facts are interpreted regarding one's motivation to come to the location, namely two aspects, demographic aspects (closeness to a place to live) and aspects of verbal distribution (word of mouth).

\section{2) Motivation}

In the category of motivation, psychological facts are obtained that motivation is not the specificity or main reason for someone visiting the area. Motivation consists of minor reasons such as releasing tired after work or walking the children.

\section{3) Affective Meaning}

In the Affective Meaning category, psychological facts are obtained that a person tends to return to the place because the atmosphere is so strong. The atmosphere created and recorded in the visitor's perception creates comfort. So that the reason for the atmosphere created creates visitors return to the study site.

\section{4) System Activity}

In the activity system category there is psychological interpretation of the intensity, duration of activity, and type of activity. The results of the analysis mentioned that visitors have a rare or not frequent intensity to the study site. However, once a long visit activity at the location is quite long ranging from one to three more hours. While the merchant category has an impact on the system of activities that lead to economic factors. Activity is a supporting factor for the length of activity that occurs.

The explanation above is a classification of the results of grouping data. The following is the overall diagram (Figure 3 ). Figure 4 is the essence of the analysis results that have been grouped into a diagram. The left side is the overall coding data category, then the right hand diagram is the result of subtracting the non-problematic category. Figure 5 is the final result of categorization along with the interrelations between them. From the data analysis there are findings regarding the patterns of visitors and traders which are explained in the following figure 5 .

Figure 5 explains the pattern of the spread of the existence of a place is verbal knowledge or word of mouth with a record of affective meaning. So that someone can reach the research location and do repetition. While Figure 6 is a big picture of the pattern of visitors and traders to meet at the research location.

\section{CONCLUSION}

The results of data analysis as a whole show that the occurrence of a phenomenon in the region is very dependent on the meaning of the space user. An understanding produces a recording of feelings that can be responded emotionally or in the form of action. This understanding indirectly explains how the origin of a behavior is formed. In a longer cycle can also explain how a pattern of activity is formed. Motivation or the purpose of someone visiting a space is not the main cause, but the meaningful affective of the environment that brings someone back to the site. Besides this type of activity also triggers repetition of phenomena in the region. In this case, informal economic activity is one reason for the continuity of the phenomenon. so these aspects are explained in the order of the hierarchy in the following table 1.

The affective meaning plays a major role in the continuity of the phenomenon. Furthermore, there are aspects of activities that are divided into types, intensities and durations. The impact of the importance of affective meaning is on the duration of activities at locations that tend to be longer, even though the intensity falls into the category rarely to location. Followed by the aspect of the existence of places naturally spread through verbal communication users to others who do not know the location. It also cannot be separated from the meaning in the minds of users who have been recorded.

\section{SUGGESTION}

The recommendations recommended in this study are:(1)Private Parties are expected to be involved and contribute to the development of regional concepts in order to improve a better environmental image; (2)The government has a major role in development is expected to deepen the context of the field so that the development of the region is right on target problem.

\section{REFERENCES}

[1] Carmona, 2008. Public space: the management dimension. New York, USA: Routledge, Taylor \& Francis group. 1

[2] Groat, Linda, dkk. 2013. Architectural Research Methods. New York : Wiley.2

[3] Gold, S.M. (1980) Recreation Planning and Development, New York: McGraw-Hill.3

[4] Hasbi, R. M. (2015) 'Peran Ruang Publik dan Privat Dalam Memproduksi dan Mengkonsumsi Ruang

[5] Laurens, Joyce Marcella. (2007). Arsitektur dan Perilaku Manusia. Jakarta: PT. Grasindo.5

[6] Santoso, J. 2006. [Menyiasati] Kota Tanpa Warga. Kepustakaan Populer Gramedia Centropolis, Universitas Tarumanagara, Jakarta 